\title{
A tool for Danish buildings energy retrofit design and evaluation using dynamic energy simulations
}

\author{
Muhyiddine Jradi ${ }^{1, *}$, Henrik Engelbrecht Foldager ${ }^{1}$, and Rasmus Camillus Jeppesen ${ }^{1}$ \\ ${ }^{1}$ Center for Energy Informatics, The Maersk Mc-Kinney Moller Institute, University of Southern Denmark, 5230 Odense M, \\ Denmark
}

\begin{abstract}
In general, static tools and simplified assessment approaches are still dominating the Danish building energy retrofit market. These static tools are generally associated with a large number of assumptions and tend to neglect the overall building dynamics. This leads to major uncertainties and substantial gaps between the predicted performance, promised before retrofitting, and the real building performance after carrying out the retrofit project. To overcome these challenges, this work presents the design, development and demonstration of DanRETRO, a tool for Danish buildings energy retrofit design and evaluation. The tool uses a large database of dynamic performance simulations employing EnergyPlus, for different building types, ages and sizes, allowing a preliminary assessment of the technical, economic and environmental impacts of various retrofit measures. In this regard, the tool provides a large selection of retrofit techniques and measures along with retrofit packages. DanRETRO is intended to be a comprehensive building energy retrofit assessment tool, but at the same time being simple to use with minimal inputs. The demonstration of the tool in an office building, a single-family house and an apartment in Denmark is presented and assessed. DanRETRO evaluation results are aimed to serve as a basis to aid energy retrofit projects decision-making.
\end{abstract}

\section{Introduction}

Buildings in Denmark consume around $40 \%$ of the overall country energy consumption with a substantial share in the greenhouse gas emissions [1]. Therefore, the building sector has been prioritized, and standards for newly built buildings are progressively being tightened with strict requirements regarding design and operation, energy consumption, thermal comfort and indoor air quality. Regarding newly built buildings, the Danish building regulations, referred to as 'Danish BR' [2], have been continuously upgraded and tightened, aiming to set high demands for both buildings design and operation. These regulations have targeted the building thermal envelope specifications, energy systems design and operation, as well as thermal comfort and indoor air quality. As a major component of each of the Danish building regulations, the thermal transmittance coefficient for various building components is presented in Table 1 [3], considering different building regulations over the last decades.

On the other hand, around $79 \%$ of the existing Danish building stock was built before 1980 [4]. In this context, the Danish government has responded to the large potential of energy savings in the existing building block by launching the country's largest and most comprehensive strategy targeting existing buildings in 2012: "Strategy for the energy renovation of the existing building stock" [5]. The strategy comprises a set of initiatives, guidelines and recommendations to aid a systematic and cost-effective buildings energy retrofit projects. The initiatives target both building physical envelope and various energy systems, along with covering different aspects of building performance from the technical, economic, environmental and legislative perspectives. Thus, exceeding 40 years of service period, many of the existing buildings have already been renovated in the recent years, where the majority are most likely to be renovated in the upcoming two decades.

Table 1. Thermal transmittance coefficient by BR [3].

\begin{tabular}{|l|c|c|c|c|c|c|}
\hline \multirow{2}{*}{$\begin{array}{c}\text { Building } \\
\text { Component }\end{array}$} & \multicolumn{5}{|c|}{ U-value by Building Regulation (BR) } \\
\cline { 2 - 7 } & 1961 & 1972 & 1985 & 1998 & 2008 & 2018 \\
\hline Ext. Walls & 0.83 & 0.55 & 0.30 & 0.20 & 0.20 & 0.18 \\
\hline Roof & 0.64 & 0.43 & 0.20 & 0.15 & 0.15 & 0.12 \\
\hline Floor & 0.64 & 0.43 & 0.30 & 0.20 & 0.15 & 0.10 \\
\hline Windows & 5.03 & 3.35 & 2.90 & 1.80 & 1.50 & 1.50 \\
\hline
\end{tabular}

In terms of building energy retrofit tools, a list of tools has been presented, implemented and evaluated in

Corresponding author: $\underline{\text { mjr@mmmi.sdu.dk }}$ 
the recent years, with various approaches and for different applications. These tools could be divided considering the methodology and the calculation framework as i) data-driven methods [6], ii) normative calculation frameworks [7] and iii) physics-based modelling approaches [8]. While the data-driven and normative methods tend to be more simplified to develop and implement, tools adopting the detailed physics-based energy modelling approach provides high accuracy and sensible assessment reporting [9].

Overall, energy retrofit investigations targeting the Danish building sector has been majorly either theoretical studies or arbitrary and reactive retrofitting projects based on the building age and the need to change or upgrade [10]. Moreover, the Danish building energy retrofit market is still largely dominated by static tools and simplified assessment approaches [11]. Such tools are generally associated with a large number of assumptions at the design and implementation levels and tend to neglect the overall building dynamics. This leads to major uncertainties and substantial gaps between the predicted performance, promised before the retrofit process, and the real building performance reported after completing the retrofit project.

The official Danish building compliance and performance assessment tool, BE18 [12], has major limitations when it comes to energy retrofit design and evaluation. Although it is user friendly and simple to use, it is fully static considering the building as one large box without taking into account building dynamics, occupants' patterns and climatic conditions. With the current status of energy retrofit projects in Denmark and the expected projects in the upcoming two decades, there is an urgent need for more comprehensive and systematic tools to aid the holistic building energy retrofit decision making, taking into consideration the technical, environmental and economic impacts. In this context, this study presents the design, development and demonstration of DanRETRO, an alternative tool for Danish buildings energy retrofit design and evaluation. In its work methodology, the tool uses a large database of dynamic performance simulations employing EnergyPlus [13], for different building types, ages and sizes, yielding a preliminary assessment of the technical, economic and environmental impacts of various retrofit measures. The tool has a set of built-in selection of retrofit techniques and measures in addition to specific retrofit packages. DanRETRO design, development and implementation in an office building, a single-family house and an apartment in Denmark is presented and assessed.

\section{Baseline Models Development}

The core part in the development of the DanRETRO tool is building up the holistic database of dynamic performance simulations, which will form the backbone of energy retrofitting design, evaluation and reporting. With the aim of developing a simple, yet comprehensive and generic tool for energy retrofit, four case study buildings were considered covering residential and office buildings as follows: 1) 1-story house, 2) 2-story house, 3) Multi-story apartment building and a 4) Multi-story office building.

The building modelling and performance simulation methodology developed by Jradi et al. [14] is used in this work, considering a package of tools. Sketchup Pro is used to draw the $3 \mathrm{D}$ architectural models of the buildings. These 3D models are then imported to OpenStudio to develop the building energy model with all specifications and characteristics including thermal building envelope, constructions, materials, devices, HVAC systems, loads, occupancy patterns and weather conditions. Finally, the validated building energy modelling and simulation engine of EnergyPlus is used to run and report the performance simulations for each case study. The first step in dealing with the case study buildings is the development of the 3D architectural models. In doing so, standard Danish residential and office building plans and geometry patterns were considered. Fig. 1 depicts the Sketchup Pro 3D models developed for the a) 1-story house, b) 2-story house and the c) multi-story apartment building. It shall be noted that each floor indoor area is considered to be $150 \mathrm{~m}^{2}$.

Then, the different 3D models developed are imported to OpenStudio to further develop the energy performance model. As the tool is planned to deal with various buildings from different timespans (or of different age), eight versions of each case study buildings were considered. This means that 32 energy models were developed in total. For example, eight versions of an office building are used depending on the period when the building was constructed as follows:

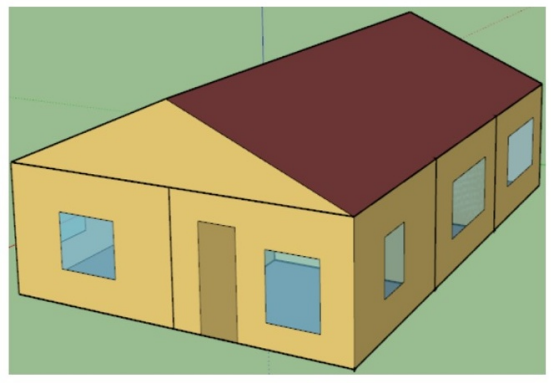

(a)

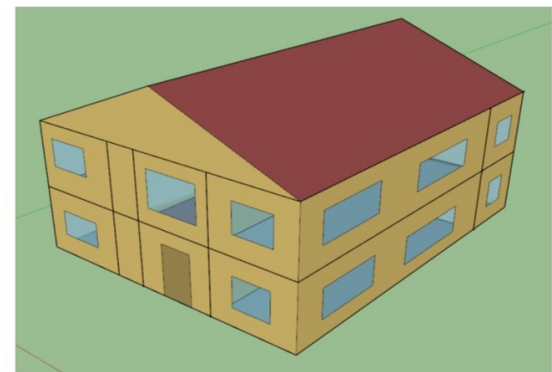

(b)

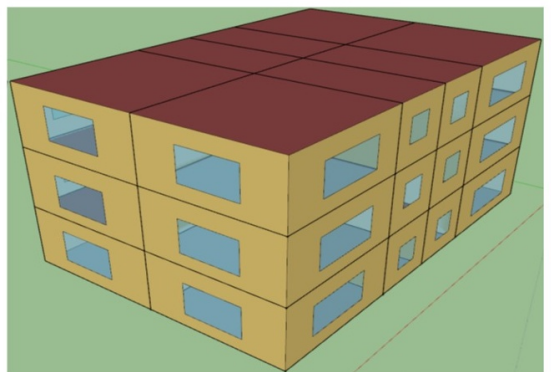

(c)

Fig. 1. 3D models developed for the (a) 1-story house, (b) 2-story house and the (c) multi-story apartment building. 
a. Office building built between the 60's and 70's

b. Office building built in the 80 's

c. Office building built in the 90's with no mechanical ventilation system

d. Office building built in the 90's with a mechanical ventilation system

e. Office building built in the 2000's with no mechanical ventilation system

f. Office building built in the 2000's with a mechanical ventilation system

g. Office building built after 2015

These scenarios were considered as they fit with the Danish building regulations issued in the last 60 years. In the development of the energy models, building physical envelope constraints set by each building regulation for the respective considered year were respected along with the set building energy consumption allowed by each building regulation throughout the decades. Regarding the energy systems, district heating was employed in all models to provide the heating demands, and mechanical ventilation was installed in models as an option from the 1990's period and so forth. Moreover, lighting, equipment, loads and schedules were defined for the different cases, differentiating between the residential cases and the office building case. In terms of occupancy, it was assumed that a residential house has a family of 4, two adults and two children.

The final stage in building the simulations database is running the 32 models using EnergyPlus, where each case was calibrated regarding heating end electricity consumption, considering the set values in the corresponding building regulation. Table 2 provides an overview on the base case 32 scenarios, with energy consumption resulted after calibration. The maximum acceptable uncertainty during models' calibration against the building regulation numbers is around $5 \%$.

Table 2. Base case scenarios energy simulation results.

\begin{tabular}{|c|c|c|c|c|}
\hline & \multicolumn{2}{|c|}{$\begin{array}{l}\text { 1-story House } \\
\left(150 \mathrm{~m}^{2}\right)\end{array}$} & \multicolumn{2}{|c|}{$\begin{array}{l}\text { 2-story House } \\
\left(300 \mathrm{~m}^{2}\right)\end{array}$} \\
\hline Consumption (MWh) & Heat & Elec & Heat & Elec \\
\hline Before 60's & 49.8 & 5.9 & 104.3 & 12.2 \\
\hline 60’s-70's & 32.4 & 5.6 & 69.4 & 11.6 \\
\hline 80 's & 19.5 & 5.3 & 42.7 & 11.1 \\
\hline 90’s (V) & 12.3 & 5.1 & 27.7 & 10.6 \\
\hline 90's & 12.3 & 5.1 & 26.4 & 10.0 \\
\hline 2000's (V) & 10.3 & 5.0 & 22.3 & 10.3 \\
\hline 2000’s & 10.3 & 5.0 & 22.6 & 9.8 \\
\hline \multirow[t]{2}{*}{2015} & 5.7 & 4.9 & 12.2 & 10.1 \\
\hline & \multicolumn{2}{|c|}{$\begin{array}{l}\text { Apartment } \\
\left(450 \mathrm{~m}^{2}\right)\end{array}$} & \multicolumn{2}{|c|}{$\begin{array}{c}\text { Office } \\
\left(460 \mathrm{~m}^{2}\right)\end{array}$} \\
\hline Consumption (MWh) & Heat & Elec & Heat & Elec \\
\hline Before 60's & 149.4 & 17.9 & 178.4 & 21.0 \\
\hline 60’s-70's & 97.2 & 16.5 & 116.4 & 19.5 \\
\hline 80 's & 58.6 & 15.7 & 71.1 & 19.1 \\
\hline 90’s (V) & 36.9 & 16.2 & 43.8 & 18.8 \\
\hline 90’s & 37.1 & 15.1 & - & - \\
\hline 2000's (V) & 30.6 & 15.7 & 37.7 & 18.5 \\
\hline 2000's & 30.9 & 15.1 & - & - \\
\hline 2015 & 17.1 & 14.5 & 20.4 & 17.8 \\
\hline
\end{tabular}

It should be noted that for the office case, only offices with ventilation system are considered for the 90's and 2000's cases. Label (V) in table 2 characterizes the scenarios which are associated with a mechanical ventilation system installation.

\section{Retrofit Measures Implementation}

The building energy models for the 32 case scenarios developed and calibrated against building regulations data, will be used as a basis to implement a set of energy retrofit measures and simulate the impact in each case. The impacts are reported in the form of electricity savings, heating savings, operational costs reduced, and $\mathrm{CO}_{2}$ emissions eliminated. A list of improvement measures is considered targeting thermal building envelope, energy systems upgrade as well as raising the building intelligence level in terms of systems and equipment control and management. The considered retrofit measures are listed in Table 3.

Table 3. Energy retrofit measures.

\begin{tabular}{|c|c|}
\hline \multirow{4}{*}{$\begin{array}{l}\text { Thermal } \\
\text { Envelope }\end{array}$} & 1. Roof Insulation \\
\hline & 2. Walls Insulation \\
\hline & 3. Floor Insulation \\
\hline & 4. Windows Upgrade \\
\hline \multirow{3}{*}{ Heating } & 5. Heating Setpoint Management \\
\hline & 6. Heating Circulation Pump Upgrade \\
\hline & 7. Adaptive Heating Implementation \\
\hline \multirow{6}{*}{ Ventilation } & 8. Ventilation Heat Exchanger Installation \\
\hline & 9. Demand-Controlled Ventilation \\
\hline & 10. Ventilation Fan Upgrade \\
\hline & 11. Ventilation Pre-heating \\
\hline & 12. $\mathrm{CO}_{2}$-Based Ventilation \\
\hline & 13. Temperature-Based Ventilation \\
\hline \multirow{3}{*}{ Lighting } & 14. Daylight Sensors Installation \\
\hline & 15. Motion Sensors Installation \\
\hline & 16. LED lights Implementation \\
\hline Equipment & 17. Electrical Equipment Upgrade \\
\hline Renewables & 18. PV system Installation on the Roof \\
\hline
\end{tabular}

In the case of the building thermal envelope, the four measures address adding insulation to the roof, walls and floor in addition to windows upgrade. What identifies how much insulation is to be added is the condition that the resulting component will have a U-value that complies with the BR18 Danish building regulation being the aim in each case. For example, this means in the case of a house from the 80's, appropriate insulation is added to the wall so the U-value of the wall would be equivalent to the value set in the BR18 for exterior walls as shown in Table 1. For the lighting systems, switching 
to LED lights is considered, as well as installing daylight sensors or motion sensors to improve the control of the room level devices. In terms of the ventilation system, six measures are considered, both on the level of the physical component upgrade and on the level of the ventilation system control and operation. The same goes for the heating system case, with measures targeting the hot water circulation pump as well as heating setpoint management and adaptive heating strategy implementation. Moreover, a renewable energy option is included in the form of adding a PV solar system on the roof to generate free electricity.

Each of the 18 retrofit measures listed in Table 3 are implemented in the 32 model scenarios developed earlier for the 4 types of buildings. Thus, each measure is implemented solely in each of the model cases to assess the impact from the technical, economic and environmental levels. After simulating the individual energy retrofit measures, a set of six retrofit packages were developed and simulated in each of the models considered. Each of the packages is a combination of two or more of the individual energy retrofit measures. The six packages included in the current version of DanRETRO are as follows:

- P1: Insulating walls and roof

- P2: Insulating walls, roof and floor and upgrading windows

- P3: Upgrading electric equipment, LED lights, motion sensors and solar PV system

- P4: Upgrading the ventilation system with an energy efficient fan, heat exchanger and preheating loop, and enabling demand-controlled ventilation.

- P5: Managing heating setpoint, implementing adaptive heating and upgrading the hot water circulation pump

- P6: Implementing daylight and motion sensors, enabling demand-controlled ventilation, lowering heating setpoint and implementing adaptive heating pattern.

As presented above, the first two packages target the building thermal envelope, where the third package deals with the lighting and electrical devices. The fourth package targets the ventilation system and the fifth one targets the heating system. In addition, an energy management package is included at the end targeting the building management and automation at various levels.

The different energy retrofit measures along with the six improvement packages are implemented in all the developed building models scenarios. The results for heating consumption, electricity consumption, operational costs and $\mathrm{CO}_{2}$ emissions are reported and stored in a centralized database to be used as a basis for DanRETRO development and energy retrofit design and evaluation.

\section{DanRETRO Development}

As mentioned earlier, the dynamic energy simulations carried out on the various versions of the four case study building types are used as a basis for the development of the DanRETRO tool. The aim is to have a comprehensive tool which takes into account the building dynamics and characteristics in the evaluation and assessment of energy retrofit options. At the same time, DanRETRO is meant to be simple to use by a wide range of users, with minimal generic inputs which are easy to collect. As a result, DanRETRO will provide a preliminary design and evaluation of the retrofit project to aid the decision-making. Figure 2 provides an overview on the tool function flow diagram.

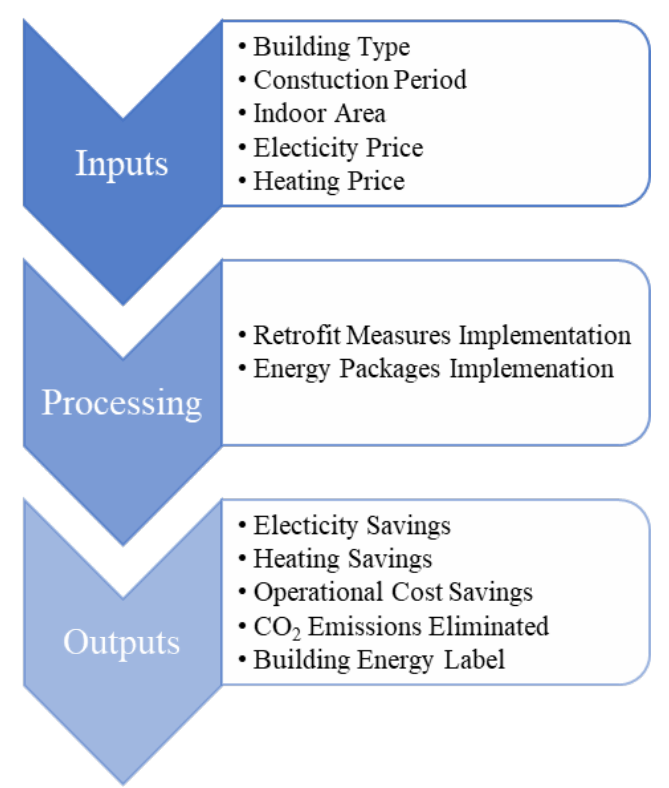

Fig. 2. DanRETRO tool function flow diagram.

In terms of the tool development environment, the Google Sheets application was considered, being generic, universal and easy to access and use. Thus, a friendly and colourful user interface was built with a tool main sheet for inputs and outputs along with multiple supporting sheets comprising the simulations database. When the user provides the required inputs, the tool fetches the sheet that corresponds to the building type and age and thus the results for retrofit assessment are reported. Regarding the tool inputs, DanRETRO needs five inputs to carry out the processing and report the results. The building type and the construction period inputs are drop-down menu inputs where the user chooses the type of the building under investigation and the period when the building was constructed or last retrofitted. Three more inputs are needed, the building indoor area, heating and electricity prices.

Based on the inputs provided by the user, the tool carries out the processing and calculation phase and reports the results for the 18 retrofit measures considered as well as the six energy packages. In the reporting phase, electricity and heating savings are reported, in addition to the operational cost savings and the $\mathrm{CO}_{2}$ emissions eliminated in each case of the above retrofit measures. In addition, the tool reports the current building energy label and the resulted energy label in each case of retrofit. This energy label calculation is performed based on the guidelines and recommendations of the Danish building regulation, and through 
evaluating the primary energy consumption in $\mathrm{kWh} / \mathrm{m}^{2}$ by Equation (1). The electricity consumption excluding equipment is multiplied by 2.5 and the heating consumption is multiplied by 1 , and the total is divided by the total indoor area of the building.

$$
\text { Prim. Energy }=[(\text { Elec }- \text { Equip }) .2 .5+\text { Heat.1]/Area }
$$

Moreover, Table 4 provides an overview on the different building labels as classified by the Danish building regulation and the associated maximum primary energy consumption for each class. DanRETRO reports both the current and future energy label of the building in each scenario of energy retrofit measures implementation.

Table 4. Building energy label vs Primary energy.

\begin{tabular}{|c|c|c|}
\hline Energy Label & $\begin{array}{c}\text { Residential } \\
\left(\mathrm{kWh} / \mathrm{m}^{2} \text {.year }\right)\end{array}$ & $\begin{array}{c}\text { Non-Residential } \\
\left(\mathrm{kWh} / \mathrm{m}^{2} . \text { year }\right)\end{array}$ \\
\hline A2020 & 27 & 33 \\
\hline A2015 & $30+1000 / \mathrm{A}$ & $41+1000 / \mathrm{A}$ \\
\hline A2010 & $52.5+1650 / \mathrm{A}$ & $71.3+1650 / \mathrm{A}$ \\
\hline $\mathrm{B}$ & $70+2200 / \mathrm{A}$ & $95+2200 / \mathrm{A}$ \\
\hline $\mathrm{C}$ & $110+3200 / \mathrm{A}$ & $135+3200 / \mathrm{A}$ \\
\hline $\mathrm{D}$ & $150+4200 / \mathrm{A}$ & $175+4200 / \mathrm{A}$ \\
\hline $\mathrm{E}$ & $190+5200 / \mathrm{A}$ & $215+5200 / \mathrm{A}$ \\
\hline $\mathrm{F}$ & $240+6500 / \mathrm{A}$ & $265+6500 / \mathrm{A}$ \\
\hline $\mathrm{G}$ & $>240+6500 / \mathrm{A}$ & $>265+6500 / \mathrm{A}$ \\
\hline
\end{tabular}

\section{DanRETRO Demonstration}

After the design and development of DanRETRO, in this section three case study buildings are considered to implement and demonstrate the tool and provide energy retrofit design and assessment. The three considered case study buildings, depicted in Fig.3, are located in different Danish municipalities, a single-family house in Munkebo, an apartment in Ringe and an office building in Odense. The three considered buildings are built in different time periods with different indoor floor area.

The three buildings considered for the tool demonstration are planned to be retrofitted in the upcoming years. Therefore, DanRETRO results will serve as a preliminary assessment and evaluation of the potential of implementing various energy retrofit measures and packages. In this manner, the preliminary analysis is set to aid the decision making of the retrofit projects in the three sites. Overall specifications of each building, imported as inputs to DanRETRO, are listed in Table 5.

The next three figures (Fig. 4-6) are screenshots from DanRETRO interface showing the information related to the implementation of the tool in the three case study buildings considered. In each figure, the building specifications as well as the current energy label is provided. In addition, the full results regarding the implementation of the various retrofit measures and energy packages are reported. This includes the technical, economic and environmental impacts for each case. Moreover, the energy label after each alteration is also reported as part of the retrofit evaluation.

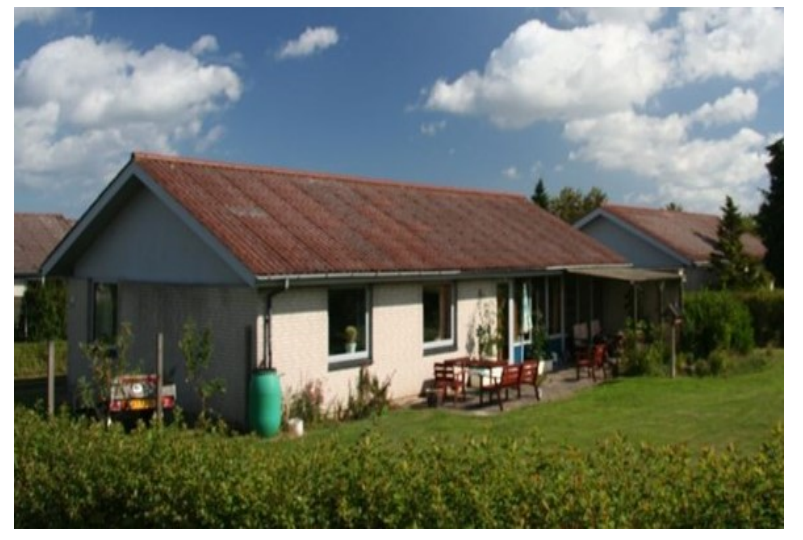

(a)

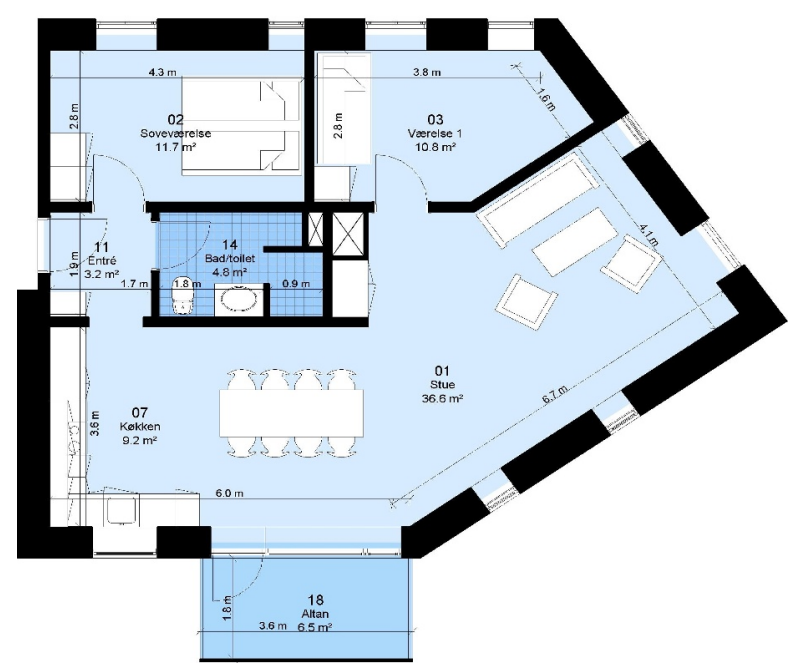

(b)

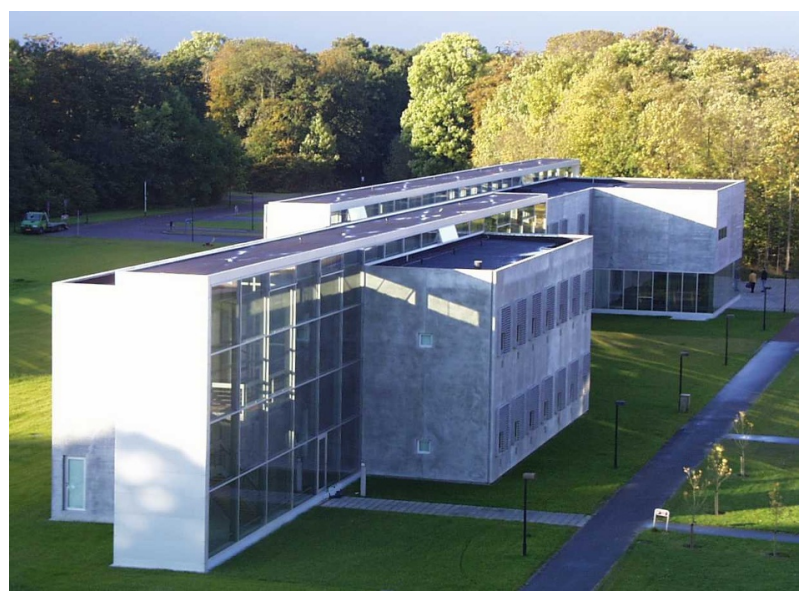

(c)

Fig. 3. The (a) single-family house, (b) apartment and (c) office building considered for demonstration. 
Table 5. Case Study Buildings Specifications.

\begin{tabular}{|l|c|c|c|}
\hline & $\begin{array}{c}\text { Single } \\
\text { House }\end{array}$ & Apartment & $\begin{array}{c}\text { Office } \\
\text { Building }\end{array}$ \\
\hline Location & Munkebo & Ringe & Odense \\
\hline $\begin{array}{l}\text { Construction } \\
\text { Year }\end{array}$ & 1963 & 1981 & 1994 \\
\hline $\begin{array}{l}\text { Indoor Area } \\
\text { m }^{2} \text { ) }\end{array}$ & 91 & 112 & 2552 \\
\hline $\begin{array}{l}\text { Heating } \\
\text { System }\end{array}$ & $\begin{array}{c}\text { District } \\
\text { Heating }\end{array}$ & $\begin{array}{c}\text { District } \\
\text { Heating }\end{array}$ & $\begin{array}{c}\text { District } \\
\text { Heating }\end{array}$ \\
\hline $\begin{array}{l}\text { Ventilation } \\
\text { System }\end{array}$ & No & No & Yes \\
\hline $\begin{array}{l}\text { Elec. Price } \\
\text { (DKK/kWh) }\end{array}$ & 2.2 & 2.2 & 2.2 \\
\hline $\begin{array}{l}\text { Heat Price } \\
(\mathrm{DKK} / \mathrm{kWh})\end{array}$ & 0.443 & 0.341 & 0.516 \\
\hline
\end{tabular}

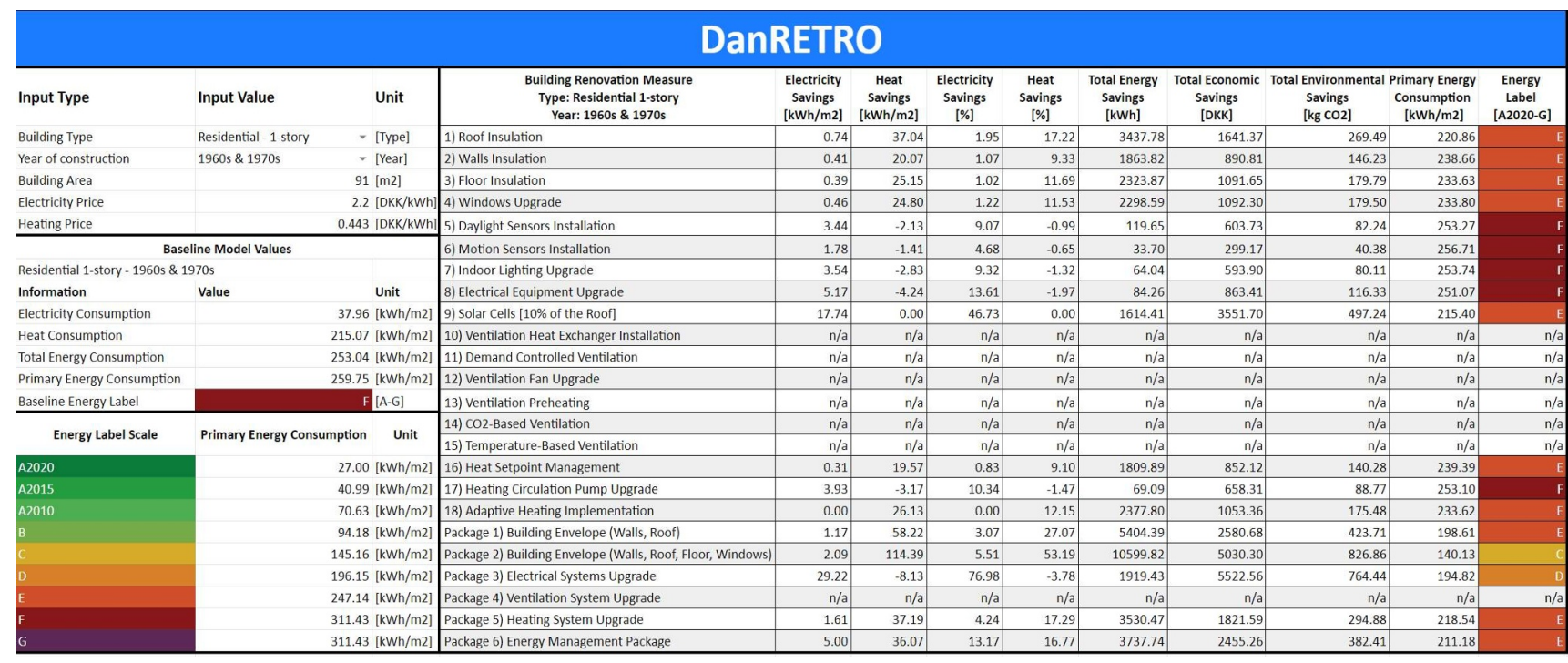

Fig. 4. DanRETRO results for the single-family house case.

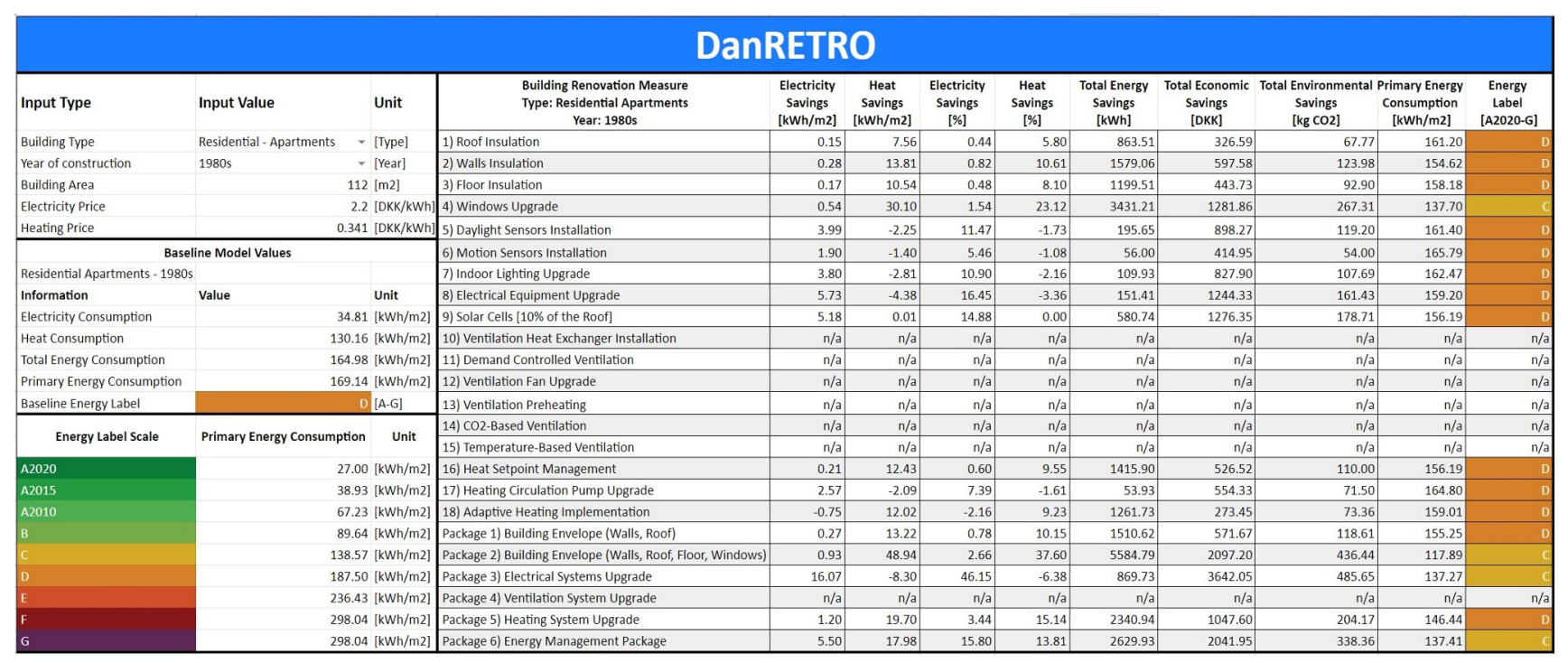

Fig. 5. DanRETRO results for the apartment case. 


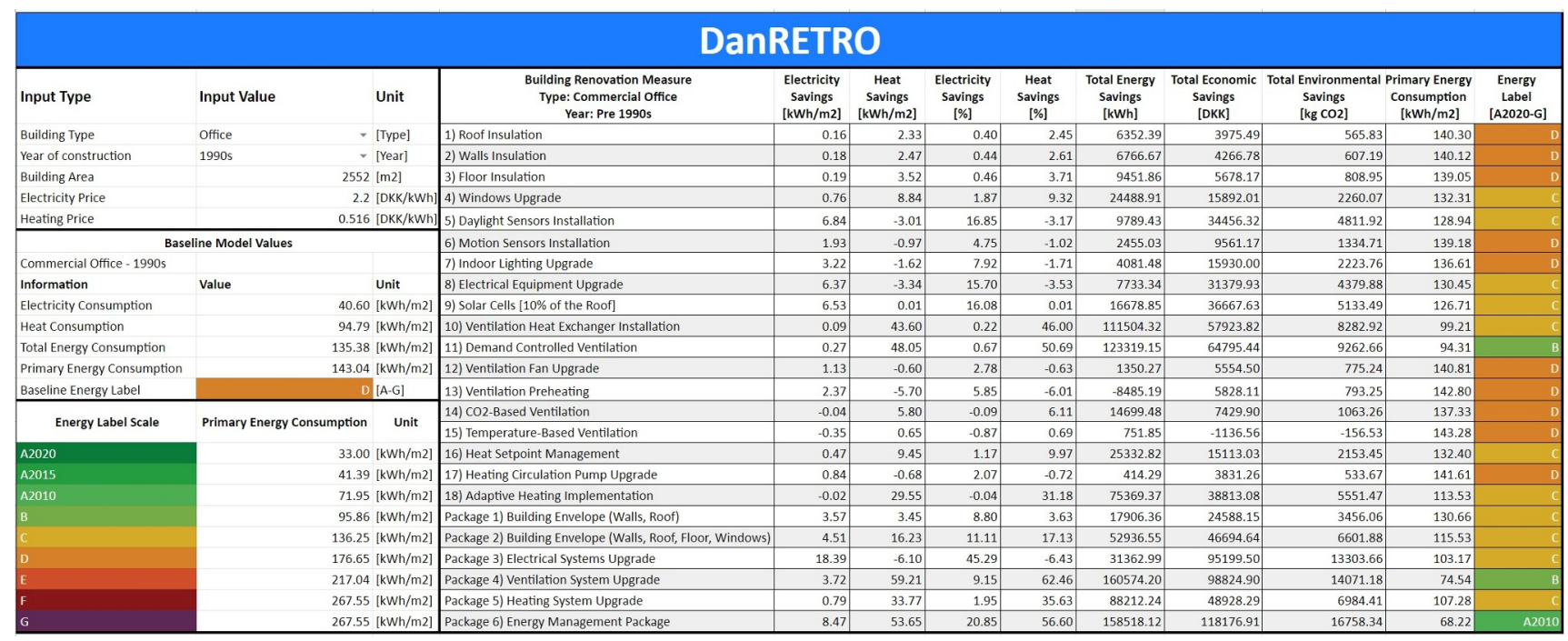

Fig. 6. DanRETRO results for the office building case.

\section{Results and Analysis}

The results of the energy retrofit design and assessment presented by DanRETRO for the three case study buildings considered will be discussed and evaluated in this section. As a starting point, there is some difference in terms of the buildings base-case labelling as both the apartment and the office building are classified as level 'D', based on the Danish building regulation categorization, whereas the single-family house is labelled as ' $F$ ', with a baseline primary energy consumption exceeding $250 \mathrm{kWh} / \mathrm{m}^{2}$.year. This is obviously directly linked to the buildings age, where the house is built in the 1963, with almost 57 years with no retrofitting. It shall be mentioned that the acceptable existing building labelling based on the Danish building regulations is level ' $\mathrm{C}$ ', whereas newly built buildings shall comply at least with level A2010. Therefore, considering the base case labelling, the three buildings are in need for an energy retrofit to improve the energy performance and thus enhance the corresponding label.

For the single-family house case, it is shown from the results that although the retrofit measures could improve the building performance drastically, none of these measures can raise the building label to ' $\mathrm{C}$ '. Saying that, the solar cells implementation is found to yield the highest savings on the annual electricity consumption and the roof insulation would provide around $17 \%$ savings on the heating consumption. In terms of the energy improvement packages, the two favourable packages are the whole building envelope package and the electrical systems upgrade package. As a summary, it seems sensible, considering the building age, to concentrate on improving the building envelope first, allowing to reach building level ' $\mathrm{C}$ ', then considering additional improvements on the systems level.

For the apartment case, the results are totally different. Considering the primary energy savings, the most favourable energy retrofit measure is upgrading the windows, which is the only measure being able to raise the building level to ' $\mathrm{C}$ '. In terms of heating savings, windows upgrade allows saving around 23\%, where electrical equipment upgrade and solar cells implementation allows savings $16 \%$ and $14 \%$ on electricity consumption respectively. Regarding the energy improvement packages, three retrofit packages allow the building to reach level ' $\mathrm{C}$ ', which are the building envelope upgrade, electrical systems upgrade and the energy management package. The building envelope upgrade package will allow saving around $37 \%$ on the heating consumption with a resulting primary energy consumption of $117 \mathrm{kWh} / \mathrm{m}^{2}$.year. It is very interesting to see that the energy management package comprising daylight and motion sensors, optimizing heating setpoint and implementing adaptive heating pattern will allow saving around $16 \%$ on the electricity consumption and $14 \%$ on the heating consumption, lowering the annual primary energy consumption from $169 \mathrm{kWh} / \mathrm{m}^{2}$ to $137 \mathrm{kWh} / \mathrm{m}^{2}$. As a summary on this case, both building envelope upgrades and improving the building management quotient will yield energy savings. The building envelope improvements is not urgent in this case compared to the single house case, however a blend between thermal envelope-targeting measures and improvements to the building systems and management patterns is capable to enhance the overall performance on the technical, economic and environmental levels.

Again, the story is different for the office building case, compared to the two previous cases. The first major difference comes up in terms of the building use, being a non-residential building, along with the relatively larger indoor conditioned area of around 2550 $\mathrm{m}^{2}$. As mentioned earlier, the building is relatively younger than the house and the apartment cases, with a major distinction in having an already installed mechanical ventilation system. The baseline building annual primary energy consumption is around 143 $\mathrm{kWh} / \mathrm{m}^{2}$, labelling it as class ' $\mathrm{D}$ ', however being very close to the ' $\mathrm{C}$ ' limit with only $8 \mathrm{kWh} / \mathrm{m}^{2}$ deviation. Considering the retrofit analysis results, it is shown that multiple energy retrofit measures would allow saving substantial amount of energy and thus improving the 
building performance and its label to ' $\mathrm{C}$ '. However, a notable impact is seen on the level of the ventilation system measures, as installing a heat exchanger and implementing demand-controlled ventilation will allow saving an average of $35 \%$ on the annual primary energy consumption, with the later allowing the building to reach level ' $B$ '. Moreover, the two favourable packages for this case are found to be, upgrading the ventilation system and the energy management package implementation. In terms of the building management package, it is reported that implementing energy management patterns targeting heating, ventilation and lighting systems will allow saving around $56 \%$ on the heating consumption and $21 \%$ on the electricity consumption. As a result, the annual primary energy consumption is reduced by $53 \%$, reaching $68 \mathrm{kWh} / \mathrm{m}^{2}$, and raising the building label dramatically from class ' $\mathrm{D}$ ' to class 'A2010'. As a summary, it is clear that building envelope upgrade is not the priority for this case, both from the technical and economic perspective. Obviously, the ventilation system improvement is a point to consider, specifically adding a heat recovery unit. In addition, improving the building intelligent quotient and targeting the control and management of energy systems is key to improve the overall performance and raising the building rating to an encouraging 'A2010' label. Regarding the measures to consider in this aspect, demand-controlled ventilation comes at the top of the list, followed by adaptive heating implementation and daylight sensors installation.

\section{Conclusion}

In this paper, DanRETRO an innovative tool for Danish buildings energy retrofit design and assessment is presented and demonstrated. Unlike the conventional static and tabulated tools dominating the market, DanRETRO uses a large database of dynamic performance simulations employing EnergyPlus, considering different building types, ages and sizes, allowing a preliminary assessment of the technical, economic and environmental impacts of various retrofit measures. The tool design, in terms of the dynamic models' development, calibration, energy improvement measures and packages simulation and simulations database building is presented. The implementation of DanRETRO along with the retrofit evaluation and assessment in three case study buildings are reported and analysed. The buildings are located in different Danish municipalities, a single-family house in Munkebo, an apartment in Ringe and an office building in Odense. Based on the reported results, it could be noted that the recommendations for the favourable measures and packages to consider in each case are largely different. While building envelope upgrades is the priority in one case, targeting the ventilation system is the favourable package to consider in another case. The three considered buildings are planned to be retrofitted in the upcoming years. Thus, DanRETRO results will serve as a preliminary assessment and evaluation of the retrofit projects to aid the decision-making in the three sites.
This study presented the first version of DanRETRO which was intended to be comprehensive but simple to use with minimal inputs. In the next versions of the tool, additional types of buildings are to be considered, including schools and retail stores. Moreover, additional retrofit measures and improvement packages are to be integrated in the database. In terms of the analysis and approach, future work would include a more detailed economic analysis, by not only considering the operating costs but also the investment costs and the payback periods of each retrofit measure, as well as a combined technical and economic optimization process.

This work was supported by the COORDICY Project, funded by Innovation Fund Denmark, ID number: 4106-00003B, and the BuildCOM project, funded by the Danish Energy Agency under the Energy Technology Development and Demonstration Program (EUDP), ID number: 64019-0081.

\section{References}

1. J. Rose, K.E. Thomsen, Energy Procedia 78, 10091014 (2015)

2. Building Regulation BR 18, Bygningsreglementet (2018). http://bygningsreglementet.dk/

3. V.H. Kjærbye, A. Larsen, M. Togeby, Ea Energy Analyses: Copenhagen, Denmark, (2010)

4. M. Jradi, B.N. Jorgensen, C.T. Veje, Energy Build. 158, 62-76 (2018).

5. Strategy for energy renovation of Buildings, Danish Ministry of Climate, Energy and Building. https://ec.europa.eu/energy/sites/ener/files/document s/2014_article4_en_denmark.pdf, May (2014).

6. Building Performance Database (BPD). Available online: https://bpd.lbl.gov/ (accessed on 15 May 2019).

7. Z. Wang, Y. Chen, Y. Li, Energy Build. 195, 51-67 (2019).

8. Commercial Building Energy Asset Scoring Tool. US Department of Energy, Office of Energy Efficiency \& Renewable Energy (2017), https://buildingenergyscore.energy.gov

9. H.E. Foldager, R.C. Jeppesen, M. Jradi, Sustainability 11, 3794-3813 (2019).

10. M. Pomianowski, Y.I. Antonov, P. Heiselberg, Energy Procedia 158, 2847-285 (2019).

11. M. Jradi, C. Veje, B.N. Jørgensen, Proceedings of the 2018 Building Performance Modeling Conference and SimBuild Co-Organized by ASHRAE and IBPSA-USA ASHRAE, Chicago, IL, USA, 26-28 September (2018); pp. 478-485.

12. BE18 Tool, Danish Building Research Institute (2018), https://be18.sbi.dk/be/

13. EnergyPlus ver. 9.2.0, U.S. Department of Energy's (DOE) Building Technologies Office (BTO), (2019) https://energyplus.net/

14. M. Jradi, C. Veje, B.N. Jørgensen, Energy Build. 151, 306-319 (2017). 